DOI: $10.20535 / 2410-8286.235940$

\title{
ATTRIBUTES OF EFFECTIVE FOREIGN LANGUAGE TEACHERS: INSIGHTS FROM UKRAINE
}

\author{
Marianna Levrints (Lőrincz) \\ Ferenc Rákóczi II Transcarpathian Hungarian College of Higher Education, Berehove, Ukraine \\ marianna@kmf.uz.ua
}

Svitlana Myshko

Uzhhorod National University, Uzhhorod, Ukraine

svitlana.myshko@uzhnu.edu.ua

\author{
Kateryna Lizák \\ Ferenc Rákóczi II Transcarpathian Hungarian College of Higher Education, Berehove, Ukraine \\ lizak.kati1@gmail.com
}

\begin{abstract}
The paper set out to explore pre-and in-service foreign language teachers' perceptions of attributes of effective teachers in Ukraine within a framework developed by the authors of the study to unravel the construct of effective language teaching. Two groups of pre-service $(n=105)$ and in-service $(n=127)$ teachers were recruited using a snowball sampling technique. The independent samples t-test and MANOVA statistical procedures were utilised to analyse and compare data generated from a self-report questionnaire. The findings indicated that the highest value was assigned to the performance category of teacher effectiveness, followed by the prerequisite category, including teacher competence, with the lowest value attached to the output category. A considerable degree of convergence was observed in students' and teachers' views on many attributes of teacher effectiveness. Both groups endorsed such attributes as clear teaching, target language proficiency, knowledge of language pedagogy, active engagement of learners, downplaying the importance of learners' test scores. Nevertheless, a statistically significant difference was detected between the perceptions of the two groups of subjects. The students accentuated teachers' personality and rapport domains, as well as motivating instruction. They also endorsed traditional approaches to language teaching in giving preference to form-focused instruction. Conversely, the teachers associated effective teaching with competence, careful planning and ongoing professional development. Teachers gave precedence to current methodological approaches in favouring meaning-focused instruction. A conclusion was drawn that teachers form more sophisticated cognitions of effective teaching in the process of professional maturation, thus implying the necessity for closer attention to the development of prospective teachers' cognitions in teacher education programmes.
\end{abstract}

Keywords: effective foreign language teachers; attributes; pre-service teachers; in-service teachers; perceptions.

\section{Introduction}

Effective foreign language teaching is high on the agenda of educational and applied linguistics research. Although concern over teacher effectiveness is presumably as old as schooling itself, it has gained remarkable currency in the last few decades due to a number of reasons. Both scholarly and public interest in the problem of effective teaching is spurred by evidence of teachers' dramatic impact on students' academic achievements, the viability of educational reforms and their pivotal role in ensuring quality education.

While the centrality of quality teaching is unequivocal, there is little consensus as to the makings of an effective teacher. Moreover, there is a dearth of studies addressing the discipline-related characteristics of effective foreign language (FL) teachers as compared to general effective teaching research. It is all the more disconcerting since the roles assumed by language teachers and expectations held of them by the information society are rapidly transforming under the influence of lingual globalisation trends.

The concept of teacher effectiveness is inevitably multidimensional (Farrell, 2015) and elusive (Stronge, 2018, p. 4) since we are dealing with as complex an activity as teaching. A well-rounded definition of FL teacher effectiveness necessitates consideration of its domain-, culture-, context-, timespecific features. Interpretation of effective teaching is essentially dynamic, emerging in line with the disciplinary developments and through the prism of political negotiations. In the field of FL education construal of effective teaching is contingent on the synergy of second language acquisition research findings, evidence and experience gleaned from practice of language teaching, as well as political discussions as to the strategic aims of language learning. For instance, in Ukraine, one of the recent trends prompted by lingual globalisation and the country's EU integration aspirations has become the adoption of

(C) Marianna Levrints, Svitlana Myshko, Kateryna Lizák. 2021. Published by Igor Sikorsky Kyiv Polytechnic Institute. This is an Open Access article distributed under the terms of the licence CC BY 4.0 
multiple government initiatives aimed at raising the level of FL education to the world standards, such as "Conceptual principles of state policy on the English language development in the sphere of higher education. Project" (2019) or "The concept of Ukraine's popularisation in the world and promotion of Ukraine's interests in the global information space" (2016). The aforementioned normative documents stipulate advanced FL mastery in its citizens to enable their active participation in the international education arena. As a corollary, an unprecedented rise of expectations has been witnessed toward the level of students' and teachers' language proficiency in the field of FL education. The adjustments in the perceptions of FL teaching quality and acquisition followed accordingly.

Effective teaching conceptualisations are domain-dependent embedded in the theories of language learning, linguistics and other related fields. In Bell's (2005) opinion, mainstream approaches and trends in FL teaching reflect common conceptions held by the professional community (p. 260). In language teaching, a shift from analytical toward utility approaches (from language analysis to language use) has brought about changes in the designation of language learning and teaching objectives. Thus, the recent developments in the foreign language teaching (FLT) methods and the spread of such approaches as content-based instruction (Leshchenko, Lavrysh and Halatsyn, 2018), task-based learning (Nychkalo et al., 2020), computer-assisted language learning (Beatty, 2010), cooperative learning (Zhang, 2010) and others delineate priorities in language education and serve as a focal point of effective FL teaching discourse. Moreover, the advent of the post-method era with prevailing "principled eclecticism" in the choice of language teaching approaches (Kumaradivelu, 2006; Tarnolosky, 2018) places greater demands on the competence of language teachers. If during the period of "dominant methodologies" language teachers were believed to be competent on condition of skilfully applying a single method, at present, taking an informed choice of didactic approaches congruent with contextual and individual needs requires more advanced accomplishments on teachers' part.

Construal of effective teaching is culture- and context-specific in that marked differences were found to exist in the perceptions of qualities of effective teachers across cultures (Tsui, 2009). With the spread of the sociocultural perspective, effective teaching interpretation has acquired localised implications (Leu, 2005, p. iii), made at micro-and macro-levels spanning the continuum from the national to the narrower levels of communities and educational institutions. Research into context- and culture-specific attributes of effective FL teaching and teachers was carried out by Barnes and Lock (2013), Park and Lee (2006), who undertook a quantitative investigation of attributes of effective language teachers in Korea. Comparative studies of English as a FL teachers' and students' perceptions of effective teaching come from the context of Iran, Slovakia (Metruk, 2020; Moradi and Sabeti, 2014; Tajeddin and Alemi, 2019). Research into characteristics of effective FL teachers in the USA was undertaken by Bell (2005), Brown (2009), to name just a few. Challenges and best practices of newly qualified FL teachers in Ukraine were studied by Komar et al. (2021). Rigorous research into attributes of effective FL teachers as ascribed by pre-service and inservice teachers in Ukraine could not be located.

To elicit empirical data available for systematisation, and to elaborate a context-sensitive comprehensive definition of effective FL teaching, incorporating recurrent in the professional discourse qualities of effective teachers, a framework was developed by the authors of the study. Extant literature analysis has generated three interrelated categories or axes along which effective teaching is evaluated and conceptualised (Bartz, 2018; Borg, 2018; Goe, Bell and Little, 2008; Muijs and Reynolds, 2011; Stronge, 2018). For the sake of convenience, they are categorised as (1) personal or prerequisite, (2) actional or performance and (3) productional or output (Levrints, 2019). Thus, the personal axis is a cluster of prerequisites the teacher brings into teaching, including qualifications, professional knowledge, skills, dispositions, motivation for teaching and personal qualities captured in the notion of competence. The actional axis refers to deploying by the teacher of personal attainments and characteristics in the professional sphere, first and foremost, in the instructional process while interacting with learners. Finally, the productional axis reflects the results of teachers' endeavours. It manifests itself in learning gains across academic and attitudinal domains. The last axis features centrally in teacher effectiveness measurements, where student scores on tests are one of the main evaluation criteria (e.g., value-added models).

Thus, FL teacher effectiveness is viewed in the study as a three-pronged complex whole decomposable into personal, actional and productional categories embedded in teachers' competence (professional knowledge, skills, dispositions, personal characteristics, etc.), enacted in professional settings (performance) and manifested in teachers' facility to establish optimal conditions, resulting in students' academic, attitudinal and personal gains within a given sociocultural milieu.

The present study seeks to lend empirical support to the above conceptualisation of the given construct and examine the weighting of effective FL teachers' attributes as ascribed by pre-and in-service teachers in 
Ukraine. As an under-researched area, our study would hopefully fill the void in the literature on effective FL teachers' attributes as perceived by student teachers and experienced teachers alike. Concerning the aim of the research, several research questions need to be addressed:

1. What attributes of effective FL teachers are considered the most and the least important by language teachers in Ukraine?

2. Are there any differences in the assumptions held by pre-and in-service teachers with regard to attributes of effective FL teachers?

3. What weighting is assigned to the three categories in the abovementioned framework of teacher effectiveness by language educators?

\section{Methods}

In order to examine attributes of effective FL teachers as viewed by language specialists, a survey research design comprising a questionnaire as a data collection tool was used, supplemented with statistical measurements to process the generated data.

\section{Participants}

The study was conducted with two groups of subjects comprising pre-service $(n=105)$ and in-service $(n=127)$ teachers of English as a FL. They were recruited using the snowball sampling technique, whereby the "selected respondents suggest other respondents" (Griffee, 2012, p. 58). The group of pre-service teachers constituted undergraduate and graduate students majoring in English Language and Literature enrolled in five Ukrainian universities. Most of them had limited teaching experience gained during a school-based practicum. The group of in-service teachers covered teaching professionals from primary to tertiary education levels who held BA, MA, PhD and DSc in English Language and Literature, with their teaching experience ranging from 1 to more than 25 years. The respondents came from different parts of Ukraine. Their participation was voluntary and anonymous, allowing for the possibility of quitting the study at any time without any consequences.

\section{Data collection and instrumentation}

The questionnaire items embraced the conceptualisation of the construct of an effective FL teacher developed by the authors of this study following an in-depth analysis of pertinent literature. Also, insightful suggestions as to the instrument's content were generated in the course of group discussions with student teachers of English as FL.

The questionnaire was made up of three parts. Its first part included 34 Likert scale type statements in which respondents were asked to indicate the level of importance they attached to language teachers' attributes. The second part required the participants to rank seven items associated with effective FL teaching in order of importance from the most (1) to the least (7) important, although equal values could be assigned to attributes that were considered equally important by the subjects. The final part of the questionnaire elicited information on the participants' teaching or learning experience respectively and demographic data.

The first part of the instrument addressed the prerequisite, actional and productional categories of the construct. The prerequisite cluster of attributes is related to the competence and personal qualities of a language teacher. Accordingly, the statements addressed language teachers' qualifications, FL fluency, content and pedagogical content knowledge, experience, dispositions toward teaching and learners, personal qualities, etc. In the actional or performance category included were statements on teachers' application of the prerequisite category in the instructional process, such as instruction (the clarity of teaching, organisation of instruction, learner engagement with the material, assessment, etc.), language education priorities (preferences given to meaning- or form-focused language teaching), communication in the FL, relationship with learners (respect for and fair treatment of learners, supportive classroom atmosphere, personalised instruction, etc.) and others. The productional or outcome category measured the respondents' perceived importance of teachers' facility to achieve positive academic, attitudinal and social outcomes in learners.

The generated data were submitted to statistical analysis using the SPSS tool package. The attributes of effective language teachers, espoused by pre-service and in-service teachers, were investigated on both item and categorical levels. The mean scores for the questionnaire's individual items and the three categories (prerequisite, actional and productional) were computed likewise. The independent samples t-test was applied to study the level of significance attached to the attributes of effective language teachers delineated in the questionnaire and to compare the responses of the two groups of subjects. Additionally, the MANOVA procedure was run to measure the level of difference, if any, in pre-and in-service teachers' perceptions of effective teachers' attributes. 
In part 2 of the questionnaire, the ranking data collection technique was used to probe the respondents' preferences on seven aspects of effective language teaching (Yu et al., 2019). Accordingly, the participants were requested to rank a set of items starting with the most (1) to the least important (7). The mean rankings scores for both groups of subjects were calculated to find out the most and the least important attributes of effective teachers.

To provide for the reliability and validity of the given instrument, the authors asked the assistance of three experts who specialise in applied linguistics to review the questionnaire for relevance, consistency and unambiguity of its items. During the second phase, a pilot study was carried out as a result of which certain items of the questionnaire were revised to eliminate vagueness. Finally, reliability statistics were run to calculate the instrument's internal consistency, which was found reliable with the index of Cronbach's Alpha .86. The questionnaire was delivered via e-mail using the Google Forms application in the spring semester of the 2020/21 academic year.

\section{Results}

The findings of the first part of the study set in Table 1 focus on the overall importance attached to attributes of effective FL teachers, their significance level and the between-group comparison of variables. As can be observed from the data, the respondents ascribed special importance to teachers' involving learners in communication in the target language (TL) $(\mathrm{M}=4,7629)$, fair treatment of learners $(\mathrm{M}=4,7414)$, clear teaching $(M=4,7328)$, TL proficiency $(M=4,7026)$, positive classroom atmosphere $(M=4,6940)$, respect for learners $(M=4,6595)$, making instruction enjoyable and interesting $(M=4,6552)$, engaging all learners with the course material $(M=4,6114)$, using varied teaching methods $(M=4,5862)$, motivation for teaching $(\mathrm{M}=4,5603)$, knowledge of FLT methods, etc. The statements receiving the least endorsement were form-focused language teaching $(M=3,9784)$, teaching experience $(M=4,1299)$, learners' academic gains $(M=4,2371)$ and the need for modification of teacher's speech when talking to their learners $(M=4,2629)$. The inferential statistics analysis data displayed in the last column of Table 1 indicates a considerable degree of convergence in teachers' and students' views on many of the statements. However, the t-test results indicated a substantial difference for the following items: lesson preparation and planning of instruction $(\mathrm{t}=4,646, \mathrm{df}=226,628, \mathrm{p}=.000)$, professional development $(\mathrm{t}=2,728, \mathrm{df}=228,317, \mathrm{p}=.007)$, teacher clarity $(\mathrm{t}=2,796, \mathrm{df}=221,181, \mathrm{p}=.006)$, adjustment of teacher talk $(\mathrm{t}=2,695, \mathrm{df}=224,68, \mathrm{p}=.008)$, knowledge of FLT methods $(\mathrm{t}=2,47, \mathrm{df}=226,137, \mathrm{p}=.014)$, teachers' intelligence and erudition $(\mathrm{t}=2,294$, $\mathrm{df}=204,925, \mathrm{p}=.023)$, personality characteristics such as kindness, availability to students $(\mathrm{t}=2,354$, $\mathrm{df}=227,772, \mathrm{p}=.019)$, making learning enjoyable and interesting $(\mathrm{t}=1,263, \mathrm{df}=215,892, \mathrm{p}=.027)$, stimulation of speech production by learners $(\mathrm{t}=2,133, \mathrm{df}=189,279, \mathrm{p}=.034)$, objective assessment $(\mathrm{t}=2,071$, $\mathrm{df}=216,108, \mathrm{p}=.038$ ).

Table 1. Means, standard deviations and p-values

\begin{tabular}{|ll|l|l|l|}
\hline An effective FL teacher is someone who... & mean & std. d. & p-value \\
\hline 1. has relevant qualifications (diploma, certificate etc.) & teacher & 4,4240 &, 81581 &, 837 \\
& student & 4,4519 &, 69506 & \\
& Total & $\mathbf{4 , 4 3 6 7}$ &, 76184 & \\
\hline 2. demonstrates a high level of FL proficiency & teacher & 4,6560 &, 66118 &, 249 \\
& student & 4,7596 &, 51190 & \\
& Total & $\mathbf{4 , 7 0 3 1}$ &, 59900 & \\
\hline 3. has a sound knowledge of linguistics, TL culture and teacher & 4,4880 &, 74721 &, 409 \\
related disciplines & student & $\mathbf{4 , 4 1 3 5}$ &, 71883 & \\
& Total & $\mathbf{4 , 4 5 4 1}$ &, 73380 & \\
\hline 4. has a sound knowledge of the FLT methods, pedagogy teacher & 4,6560 &, 71959 &, 014 \\
and related disciplines & student & 4,4327 &, 66485 & \\
& Total & $\mathbf{4 , 5 5 4 6}$ &, 70265 & \\
\hline 5. has relevant experience & teacher & 4,1440 &, 87717 &, 409 \\
& student & 4,1346 &, 90369 & \\
\hline T. has a high level of intelligence and erudition & Total & $\mathbf{4 , 1 3 9 7}$ &, 88736 & \\
& teacher & 4,6480 &, 59914 &, 023 \\
& student & 4,4615 &, 66716 & \\
\hline
\end{tabular}




\begin{tabular}{|c|c|c|c|c|}
\hline 7. engages in professional development on a regular basis & $\begin{array}{l}\text { teacher } \\
\text { student } \\
\text { Total }\end{array}$ & $\begin{array}{l}4,3760 \\
4,1538 \\
\mathbf{4 , 2 7 5 1}\end{array}$ & $\begin{array}{l}, 71464 \\
, 63505 \\
, 68719\end{array}$ & |,007 \\
\hline 8. reflects on his/her teaching and learns from experience & $\begin{array}{l}\text { teacher } \\
\text { student } \\
\text { Total }\end{array}$ & $\begin{array}{l}4,4480 \\
4,4519 \\
\mathbf{4 , 4 4 9 8}\end{array}$ & $\begin{array}{l}92854 \\
68094 \\
, 82364\end{array}$ & ,951 \\
\hline 9. is motivated, demonstrates interest and enthusiasm & $\begin{array}{l}\text { teacher } \\
\text { student } \\
\text { Total }\end{array}$ & $\begin{array}{l}4,5920 \\
4,5385 \\
\mathbf{4 , 5 6 7 7}\end{array}$ & $\begin{array}{l}, 75237 \\
, 60617 \\
, 68889\end{array}$ &, 587 \\
\hline 10. is charismatic, kind, available to students & $\begin{array}{l}\text { teacher } \\
\text { student } \\
\text { Total }\end{array}$ & $\begin{array}{l}4,3840 \\
4,6058 \\
\mathbf{4 , 4 8 4 7}\end{array}$ & $\begin{array}{l}, 80105 \\
, 59803 \\
72304 \\
\end{array}$ &, 019 \\
\hline 11. uses varied teaching methods and techniques & $\begin{array}{l}\text { teacher } \\
\text { student } \\
\text { Total }\end{array}$ & \begin{tabular}{|l}
4,5600 \\
4,6154 \\
$\mathbf{4 , 5 8 5 2}$
\end{tabular} & $\begin{array}{l}, 64006 \\
, 64323 \\
, 64069\end{array}$ &, 614 \\
\hline 12. thoroughly prepares and plans lessons & $\begin{array}{l}\text { teacher } \\
\text { student } \\
\text { Total }\end{array}$ & $\begin{array}{l}4,5385 \\
4,0960 \\
\mathbf{4 , 2 9 6 9}\end{array}$ & $\begin{array}{l}, 60617 \\
, 83689 \\
, 77178\end{array}$ &, 000 \\
\hline 13. explains the material clearly and meaningfully & $\begin{array}{l}\text { teacher } \\
\text { student } \\
\text { Total }\end{array}$ & $\begin{array}{l}4,6400 \\
4,8462 \\
4,7336\end{array}$ & $\begin{array}{l}, 62733 \\
41265 \\
, 54913\end{array}$ & |,006 \\
\hline 14. clearly states expectations and aims of the course & $\begin{array}{l}\text { teacher } \\
\text { student } \\
\text { Total }\end{array}$ & $\begin{array}{l}4,4560 \\
4,5962 \\
\mathbf{4 , 5 1 9 7}\end{array}$ & $\begin{array}{l}, 82798 \\
, 61564 \\
, 74091 \\
\end{array}$ &, 121 \\
\hline 15. uses effective questioning techniques & $\begin{array}{l}\text { teacher } \\
\text { student } \\
\text { Total }\end{array}$ & $\begin{array}{l}4,4320 \\
4,3558 \\
\mathbf{4 , 3 9 7 4}\end{array}$ & $\begin{array}{l}, 73326 \\
, 70941 \\
, 72196 \\
\end{array}$ & ,444 \\
\hline $\begin{array}{l}\text { 16. makes learning enjoyable/interesting (e.g. by using } \\
\text { interesting, relevant, varied tasks, materials etc.) }\end{array}$ & $\begin{array}{l}\text { teacher } \\
\text { student } \\
\text { Total }\end{array}$ & $\begin{array}{l}4,5820 \\
4,7308 \\
\mathbf{4 , 6 5 5 0}\end{array}$ & $\begin{array}{l}, 92541 \\
, 57843 \\
, 78848\end{array}$ &, 022 \\
\hline 17. engages all learners equally during the lesson & $\begin{array}{l}\text { teacher } \\
\text { student } \\
\text { Total }\end{array}$ & $\begin{array}{l}4,5760 \\
4,6538 \\
\mathbf{4 , 6 1 1 4}\end{array}$ & $\begin{array}{l}, 66313 \\
, 57063 \\
, 62271 \\
\end{array}$ & ,429 \\
\hline $\begin{array}{l}\text { 18. knows his/her students (their needs, interests, strong and } \\
\text { weak points, goals etc.) }\end{array}$ & $\begin{array}{l}\text { teacher } \\
\text { student } \\
\text { Total }\end{array}$ & $\begin{array}{l}4,3840 \\
4,5769 \\
\mathbf{4 , 4 7 1 6}\end{array}$ & $\begin{array}{l}, 73818 \\
, 74641 \\
, 74653 \\
\end{array}$ &, 063 \\
\hline 19. objectively assesses learners' knowledge & $\begin{array}{l}\text { teacher } \\
\text { student } \\
\text { Total }\end{array}$ & $\begin{array}{l}4,4615 \\
4,6320 \\
4,5546\end{array}$ & $\begin{array}{l}, 68156 \\
, 64177 \\
, 66414\end{array}$ &, 038 \\
\hline 20.prefers meaning-focused instruction & $\begin{array}{l}\text { teacher } \\
\text { student } \\
\text { Total }\end{array}$ & $\begin{array}{l}4,4560 \\
4,4423 \\
\mathbf{4 , 4 4 9 8}\end{array}$ & $\begin{array}{l}, 76732 \\
, 66576 \\
, 72145\end{array}$ &, 833 \\
\hline 21. prefers form-focused language teaching & $\begin{array}{l}\text { teacher } \\
\text { student } \\
\text { Total }\end{array}$ & $\begin{array}{l}3,9520 \\
4,0192 \\
\mathbf{3 , 9 8 2 5}\end{array}$ & $\begin{array}{l}92332 \\
, 82416 \\
, 87842 \\
\end{array}$ &, 624 \\
\hline 22.uses the TL for the most part of the lesson & $\begin{array}{l}\text { teacher } \\
\text { student } \\
\text { Total }\end{array}$ & $\begin{array}{l}4,4400 \\
4,5577 \\
\mathbf{4 , 4 9 3 4}\end{array}$ & $\begin{array}{l}, 86509 \\
, 72174 \\
, 80361 \\
\end{array}$ &, 377 \\
\hline 23.modifies his/her speech to students' proficiency level & $\begin{array}{l}\text { teacher } \\
\text { student } \\
\text { Total }\end{array}$ & $\begin{array}{l}4,1120 \\
4,4423 \\
\mathbf{4 , 2 6 2 0}\end{array}$ & $\begin{array}{l}1,00174 \\
, 69432 \\
, 88921\end{array}$ &, 008 \\
\hline 24. encourages learners to speak the TL as often as possible & $\begin{array}{l}\text { teacher } \\
\text { student }\end{array}$ & $\begin{array}{l}4,8240 \\
4,7019\end{array}$ & $\begin{array}{l}, 42244 \\
, 53752\end{array}$ &, 034 \\
\hline
\end{tabular}




\begin{tabular}{|c|c|c|c|c|}
\hline & Total & |4,7686 & |,48092 & \\
\hline \multirow[t]{3}{*}{ 25. uses genuine communication tasks } & teacher & 4,6400 &, 73397 & ,761 \\
\hline & student & 4,6731 &, 58197 & \\
\hline & Total & 4,6550 &, 66803 & \\
\hline \multirow[t]{3}{*}{ 26. establishes supportive, stress-free classroom atmosphere } & teacher & 4,6800 &, 56225 &, 788 \\
\hline & student & 4,7212 &, 52982 & \\
\hline & Total & 4,6987 &, 54696 & \\
\hline \multirow[t]{3}{*}{ 27. shows respect for all learners } & teacher & 4,6080 & ,93236 & , 327 \\
\hline & student & 4,7308 &, 50686 & \\
\hline & Total & 4,6638 & 76979 & \\
\hline \multirow{3}{*}{$\begin{array}{l}\text { 28. provides personalised instruction (teaching) taking into } \\
\text { account students' strengths, needs, interests }\end{array}$} & teacher & 4,4000 & 69561 &, 222 \\
\hline & student & 4,5192 &, 66800 & \\
\hline & Total & 4,4541 &, 68431 & \\
\hline \multirow[t]{3}{*}{ 29. treats all students fairly } & teacher & 4,7520 & ,59101 & ,971 \\
\hline & student & 4,7404 &, 52130 & \\
\hline & Total & 4,7467 &, 55925 & \\
\hline \multirow[t]{3}{*}{ 30. demonstrates commitment to learners } & teacher & 4,3920 & 90604 & 894 \\
\hline & student & 4,3846 & 68702 & \\
\hline & Total & 4,3886 & 81222 & \\
\hline \multirow[t]{3}{*}{ 31. encourages learner autonomy } & teacher & 4,5600 & 65254 &, 017 \\
\hline & student & 4,3462 & ,72097 & \\
\hline & Total & 4,4629 & 69122 & \\
\hline \multirow[t]{3}{*}{ 32. achieves positive academic outcomes in learners } & teacher & 4,1280 & 91560 &, 056 \\
\hline & student & 4,3654 &, 71132 & \\
\hline & Total & 4,2358 & 83579 & \\
\hline \multirow{3}{*}{$\begin{array}{l}\text { 33. learners of this teacher are motivated and committed to } \\
\text { learning }\end{array}$} & teacher & 4,2880 & ,78098 &, 111 \\
\hline & student & 4,4712 & 69613 & \\
\hline & Total & 4,3712 &, 74766 & \\
\hline \multirow{3}{*}{$\begin{array}{l}\text { 34. learners of this teacher experience the sense of security } \\
\text { and support in the lessons }\end{array}$} & teacher & 4,4160 & 82486 &, 754 \\
\hline & student & 4,4615 & ,66716 & \\
\hline & Total & 4,4367 &, 75606 & \\
\hline
\end{tabular}

The results of the average mean scores calculated for the three categories of the investigated construct revealed that the highest value was assigned to the actional/performance category $(M=4,5167)$, followed by the personal/prerequisite category $(M=4,4629)$, while the lowest value received the productional/output category $(\mathrm{M}=4,2479)$.

The findings of the ranking analysis displayed in Table 2 show the comparative importance of the seven variables as perceived by the respondents. The most important attributes associated with effective FL teaching are clear teaching, FL proficiency, knowledge of FLT methods, while the least important attribute is learners' academic results.

Table 2. Rankings of attributes of effective FL teachers

\begin{tabular}{|l|c|c|c|c|}
\hline & \multicolumn{4}{|c|}{ Mean ranking } \\
\hline 1- the most important, 7- the least important & students & teachers & average & p-value \\
\hline 1. Clear teaching and communication skills & 2,5333 & 2,1496 & 2,3233 &, 132 \\
\hline 2. High level of proficiency in the TL & 2,9429 & 2,2283 & 2,3836 &, 001 \\
\hline $\begin{array}{l}\text { 3. Knowledge of methods of FLT and other related } \\
\text { disciplines }\end{array}$ & 2,7524 & 2,0787 & 2,5517 &, 004 \\
\hline 4. Effective learning for all students & 3,1143 & 2,5197 & 2,7888 &, 019 \\
\hline 5. Positive classroom atmosphere & 3,30 & 2,91 & 2,9066 &, 117 \\
\hline 6. Thorough preparation, planning of teaching & 3,0762 & 2,8268 & 2,9397 &, 292 \\
\hline $\begin{array}{l}\text { 7. Positive academic outcomes in learners (e.g. test } \\
\text { results) }\end{array}$ & 3,0381 & 2,6142 & 3,08 &, 135 \\
\hline
\end{tabular}


After submitting the questionnaire data to MANOVA statistical procedure, a statistically significant difference between the in-service and pre-service teachers was found when considered on the variables included in the study's first part (Wilk's $\wedge=.534, \mathrm{f}=4,974, \mathrm{p}=.000)$. The partial eta squared was large $\left(\eta^{2}\right.$ $=.466$ ). Also, a statistically significant difference between the teachers' and students' views was detected in Part 2 of the questionnaire (Wilk's $\wedge=.927, \mathrm{f}=2,520, \mathrm{p}=.016$ ). The effect size measure yielded a medium correlation $\left(\eta^{2}=.073\right)$.

\section{Discussion}

In the present study, attributes of effective FL teachers, as perceived by pre-and in-service teachers, were examined. The independent samples t-test and MANOVA statistical procedures were utilised to analyse and compare data generated from a self-report questionnaire. The findings revealed relevant degrees of importance ascribed by language educators to the characteristics of effective FL teachers. Overall, it can be inferred from the results of the study that in making judgments on the essence of effective FL teaching, the respondents took into account teachers' skilful application of the prerequisite attributes in the instructional process. Competent organisation and implementation of instruction were endorsed by the majority of subjects as evidenced in the high means on such categories as involving all learners in speech production, treating them fairly, providing clear instruction, creating a positive classroom atmosphere, making learning interesting and relevant to students' needs, using varied teaching methods and engaging learners with the instructional material. Although some of the attributes which belong to the prerequisite category, such as high level of FL proficiency, knowledge of FLT methods, motivation and enthusiasm, were also highly valued by the respondents, they were, nevertheless, outweighed by the actional/performance category. Finally, the results of the study indicated that respondents appeared to overlook the importance of learners' gains in terms of academic and attitudinal outcomes. Presumably, Ukrainian language educators do not endorse the idea of evaluating teachers' performance based on their learners' academic outcomes, as opposed to their counterparts in other countries where test results are one of the main criteria in teacher effectiveness evaluation procedures.

On the whole, in-service teachers assigned more weighting for knowledge of language pedagogy, intelligence, ongoing professional development, lesson preparation, active involvement of learners in language output and learner autonomy. On the contrary, the prospective teachers ascribed more value to personal characteristics, such as kindness, helpfulness, charisma, clear explanation of the new material, interpersonal intelligence (knowing learners' needs, interests, strong and weak points), fair assessment and adjusting teacher talk to learners' proficiency level.

Thus, for practitioners, the profile of an effective FL teacher embraces an image of a knowledgeable professional with a sound knowledge base of the FLT methods and a high level of FL proficiency. They regularly engage in professional development, thoroughly plan instruction, actively engage learners in the lessons, provide meaning-focused teaching, encourage learner autonomy, hence, prioritise learner-centred teaching. For students, an effective FL teacher treats all learners fairly, fluently speaks the FL, makes learning enjoyable, shows respect for learners, creates a supportive classroom atmosphere conducive to learning, uses varied teaching methods, objectively assesses learners, knows his/her students, caters for their needs and prefers from-focused instruction. Comparison of the two profiles of an effective FL teacher indicated that the students accentuated the personality and rapport domains, as well as interesting, motivating instruction, as consistent with the findings of Tajeddin and Alemi (2019). On the contrary, the teachers attached high value to the competence sphere, careful planning and organisation of instruction, ongoing professional development. As opposed to students, teachers endorsed mainstream methodological approaches in favouring meaning-focused instruction. Students seemed to stick more with the traditional approaches to language teaching in giving preference to more focus on grammar. Similar findings emerged in other studies and, therefore, were not unexpected (Metruk, 2020, p. 88; Parks and Lee, 2006, p. 242). Changes taking place in teachers' perceptions as they mature professionally, point to the dynamic nature of their cognitions, spurred by experience and growth of competence. In a similar vein, Tajeddin and Alemi (2019) pointedly remark that as compared to students, in-service teachers develop a more complex conception of teaching effectiveness marking their professional growth (p. 18).

The findings of the second part of the study demonstrated that the subjects attached primary importance to clear teaching and communication skills followed by a high level of TL proficiency, which concurs with observations of Barnes and Lock (2013), Park and Lee (2006). However, the between-group comparison of responses showed that the teachers attached greater importance to language pedagogy knowledge, language proficiency and effective learning for all students. In contrast to the findings of Moradi and Sabeti (2014), the Ukrainian student teachers prioritised clear teaching over TL proficiency. 
The positive classroom atmosphere was ranked lower than the competence cluster reflected in teachers' knowledge and skilful teaching, also corroborated in the findings of Barnes and Lock (2013). Similar to the first part of the given study, the lowest ranking received learners' academic outcomes. Hence, language teachers in Ukraine do not associate teacher effectiveness with their learners' test results, thus challenging the validity of value-added teacher evaluation models in this country.

Taken together, both students and teachers demonstrated a considerable degree of convergence on many aspects of effective teaching which is in line with the findings of other researchers (e.g. Metruk, 2020). However, as shown earlier, in-service teachers' views on the effectiveness attributes significantly differed from pre-service teachers on many of the central statements, which signal their professional maturation involving more complicated construction of an effective FL teacher's image, development of a more complex set of cognitions in teachers.

\section{Conclusions}

The present paper explored the perceptions of in-service and prospective FL teachers as to the attributes of effective teachers in Ukraine. The findings of the study indicated that in making judgments on teachers' effectiveness, the respondents gave precedence to the actional/performance category, reflected in effective deliverance of course material, organisation of instruction, which was followed by the personal/prerequisite category (e.g. knowledge of the language and FLT methods, motivation for teaching), with the productional category receiving the weakest support. The between-group data comparison revealed some similarities and discrepancies in the weightings suggested for effective teachers' attributes. In teachers' view, concomitant attributes of effective FL teachers were knowledge of language pedagogy, high level of language proficiency, intelligence and erudition, ongoing professional development, planning of instruction, meaning-focused instruction. Conversely, student teachers underscored learners' fair treatment, fluency in the TL, enjoyable lessons, respect for learners, supportive classroom atmosphere, variety of teaching methods, objective assessment, catering for students' needs and preferences, form-focused instruction.

It can be inferred from the obtained results that as teachers mature professionally, their conceptualisation of effective teaching grows more sophisticated, building on experience and competence. Prospective teachers, who are at the initial stage of professionalization, focus more narrowly on rapport with learners and teachers' personality traits under the influence of experience gained in the role of learners and limited teaching experience. Given the weakest degree of endorsement of the productional category related to the outcomes of teachers' work by both groups of teachers, the validity of teacher effectiveness measurements based on learners' test results is called into question, at least in this country.

A note of caution should be offered on the generalisability of the study's results, stemming from the complexity of FL teacher effectiveness construct and a lack of its circumscribed conceptualisation in the pertinent literature. In addition, the number of subjects included in the study was rather small, and data collection took place at only one point in time. Notwithstanding its limitations, due to the paucity of research on attributes of effective FL teachers, this study would hopefully offer a valuable insight into the problem of quality language teaching and teacher education. Further research might explore attributes of ineffective teaching to provide a better understanding of the researched area.

\section{References:}

Barnes, B. D., Lock, G. (2013). Student perceptions of effective foreign language teachers: A quantitative investigation from a Korean university. Australian Journal of Teacher Education, 38(2), 19-36. http://dx.doi.org/10.14221/ajte.2013v38n2.2

Beatty, K. (2010). Teaching and researching computer-assisted language learning. London: Pearson Education. https://doi.org/10.4324/9781315833774

Bell, T. (2005). Behaviors and attitudes of effective foreign language teachers: results of a questionnaire study. Foreign Language Annals, 38 (2), 259-270. https://doi.org/10.1111/j.1944-9720.2005.tb02490.x

Bartz, D. (2018). Factors of Effective Teaching. National forum of teacher education journal, 18(3), 1-10. Retrieved March 32021 from http://www.nationalforum.com/Journals/NFTEJ/NFTEJ.htm

Borg, S. (2018). Teacher evaluation: Global perspectives and their implications for English language teaching. A literature review. Delhi: British Council.

Brown, A.V. (2009). Students' and teachers' perceptions of effective foreign language teaching: A comparison of ideals. The Modern language Journal, 93, 46-60. https://doi.org/10.1111/j.1540-4781.2009.00827.x

Farrell, T. S. C. (2015). It's not who you are! It's how you teach! Critical competencies associated with effective teaching. RELC Journal, 46(1), 79-88. https://doi.org/10.1177/0033688214568096

Goe, L., Bell, C., Little, O. (2008). Approaches to evaluating teacher effectiveness: A research synthesis. Washington, DC: National Comprehensive Center for Teacher Quality.

Griffee, D. T. (2012). An introduction to second language research methods: Design and data. Berkeley, California: TESL-EJ Publications. 
Komar, O., Kolisnichenko, A., Derkach, S., \& Kapeliushna, T. (2021). Newly qualified foreign language teachers' adaptation in profession: challenges, problems, first achievements and further prospects. Advanced Education, 17, 35-45. https://doi.org/10.20535/2410-8286.228211

Kumaravadivelu, B. (2006). Understanding language teaching. From method to post-method. London: Lawrence Erlbaum Associates.

Leshchenko, M., Lavrysh, Y., \& Halatsyn, K. (2018). The role of content and language integrated learning at Ukrainian and Polish educational systems: challenges and implication. Advanced Education, 5, 17-25. https://doi.org/10.20535/24108286.133409

Leu, E. (2005). The role of teachers, schools, and communities in quality education: A review of the literature. Washington, DC: Academy for Educational Development, Global Education Center.

Levrints (Lőrincz), M. (2019). Umovy efektyvnosti profesiynoyi diyal'nosti vchyteliv u SShA [Teacher effectiveness factors in the USA]. Zbirnyk naukovykh prats' Umans'koho derzhavnoho pedahohichnoho universytetu, 3, 110-119. http://doi.org/10.31499/2307-4906.3.2019.190339.

Metruk, R. (2020). Qualities of a good and effective teacher: Slovak EFL pre-service and in-service teachers' perspectives. Journal of Language and Education, 6(3), 80-93. https://doi.org/10.17323/jle.2020.10593

Ministry of Education and Science of Ukraine (2019). Kontseptualni zasady derzhavnoi polityky shchodo rozvytku anhliiskoi movy u sferi vyshchoi osvity. Proiekt MON [Conceptual principles of state policy on the English language development in the sphere of higher education. Project of the Ministry of Education and Science]. Retrieved May 82020 from https://mon.gov.ua/ua/news/mon-stvorilo-koncepciyu-rozvitku-anglijskoyi-v-universitetah-u-dodatku-riven-v1-obovyazkovaumova-vstupu-v2-vipusku-vikladannya-profilnih-disciplin-inozemnoyu-ta-movniskriningi?fbclid=IwAR2ICPzauy6r5JKmZYAPMKgIPn9TXxjqaekymfOGHYmmJuXkNoH1SLgQnGo

Moradi, K., Sabeti, G. (2014). A comparison of EFL teachers and EFL students' understandings of 'highly effective teaching'. Procedia-Social and Behavioral Sciences, 98, 1204-1213. https://doi.org/10.1016/j.sbspro.2014.03.535

Muijs, D., Reynolds, D. (2011). Effective teaching. Evidence and practice. (3rd ed.). Los Angels, CA: Sage.

Nychkalo N., Jinba, W., Lukianova, L., Paziura, N., Muranova, N. (2020). Use of task-based approach in teaching vocabulary to business English learners at university. Advanced education, 16, 98-103. https://doi.org/10.20535/2410-8286.215117

Park, G. P., Lee, H. W. (2006). The characteristics of effective English teachers as perceived by high school teachers and students in Korea. Asia Pacific Education Review, 7(2), 236-248. https://doi.org/10.1007/BF03031547

Stronge, J. (2018). Qualities of effective teachers ( $3^{\text {rd }}$ ed.). Alexandria, USA: ASCD.

Tajeddin, Z., Alemi, M. (2019). Effective language teachers as persons: exploring pre-service and in-service teachers' beliefs. The Electronic Journal for English as a Second Language, 22(4), 1-25. Retrieved March 52021 from http://www.teslej.org/wordpress/issues/volume22/ej88/ej88a3/

Tarnopolsky, O. (2018). Principled pragmatism, or well-grounded eclecticism: A new paradigm in teaching English as a foreign language at Ukrainian tertiary schools? Advanced Education, 10, 5-11. https://doi.org/10.20535/2410-8286.133270

Tsui, A.B.M. (2009). Teaching expertise: approaches, perspectives and characterizations. In A. Burns \& J. C. Richards (Eds.), Cambridge Guide to Second Language Teacher Education (pp. 190-197). Cambridge: Cambridge University Press.

Verkhovna Rada of Ukraine (2016). Kontseptsiia populiaryzatsii Ukrainy u sviti ta prosuvannia interesiv Ukrainy u svitovomu informatsiinomu prostori [The concept of Ukraine's popularisation in the world and promotion of Ukraine's interests in the global information space] Retrieved April 192020 from https://zakon.rada.gov.ua/laws/show/739-2016-\%D1\%80\#Text

$\mathrm{Yu}, \quad \mathrm{P} ., \quad \mathrm{Gu}, \quad \mathrm{J} ., \quad \& \mathrm{Xu}, \mathrm{H} . \quad$ (2019). Analysis of ranking data. WIREs Computational Statistics, August. https://doi.org/10.1002/wics.1483

Zhang, Y. (2010). Cooperative language learning and foreign language learning and teaching. Journal of Language Teaching and Research, 1(1), 81-83. https://doi.org/10.4304/jltr.1.1.81-83 